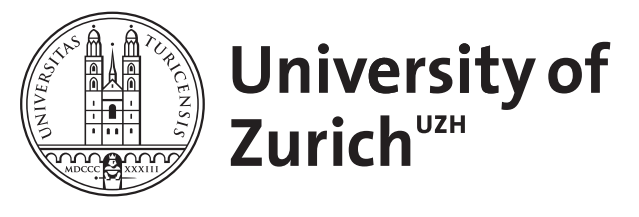

\title{
Influence of fire on the carbon cycle and climate
}

\author{
Lasslop, Gitta ; Coppola, Alysha I ; Voulgarakis, Apostolos ; Yue, Chao ; Veraverbeke, Sander
}

\begin{abstract}
Purpose of Review: Understanding of how fire affects the carbon cycle and climate is crucial for climate change adaptation and mitigation strategies. As those are often based on Earth system model simulations, we identify recent progress and research needs that can improve the model representation of fire and its impacts. Recent Findings New constraints of fire effects on the carbon cycle and climate are provided by the quantification of the carbon ages and effects of vegetation types and traits. For global scale modelling the low understanding of the human-fire relationship is limiting. Summary Recent developments allow improvements in Earth system models with respect to the influences of vegetation on climate, peatland burning and the pyrogenic carbon cycle. Better understanding of human influences is required. Given the impacts of fire on carbon storage and climate, thorough understanding of the effects of fire in the Earth system is crucial to support climate change mitigation and adaptation.
\end{abstract}

DOI: https://doi.org/10.1007/s40641-019-00128-9

Posted at the Zurich Open Repository and Archive, University of Zurich

ZORA URL: https://doi.org/10.5167/uzh-170518

Journal Article

Accepted Version

Originally published at:

Lasslop, Gitta; Coppola, Alysha I; Voulgarakis, Apostolos; Yue, Chao; Veraverbeke, Sander (2019). Influence of fire on the carbon cycle and climate. Current Climate Change Reports, 5(2):112-123.

DOI: https://doi.org/10.1007/s40641-019-00128-9 


\section{Influence of Fire on the Carbon cycle and Climate}

Gitta Lasslop, gitta.lasslop@senckenberg.de, Senckenberg Biodiversity and Climate Research Centre, Senckenberganlage 25, 60345 Frankfurt am Main, Hesse, Germany

Alysha I. Coppola, alysha.coppola@geo.uzh.ch, Department of Geography, University of Zurich, Winterthurerstrasse 190, 8057 Zurich Switzerland

Apostolos Voulgarakis, a.voulgarakis@imperial.ac.uk, Department of Physics, Imperial College London, London SW7 2AZ, United Kingdom

Chao Yue, chaoyuejoy@gmail.com, State Key Laboratory of Soil Erosion and Dryland Farming on the Loess Plateau, Northwest A\&F University, Yangling, Shaanxi 712100, PR China

Sander Veraverbeke, s.s.n.veraverbeke@vu.nl, Vrije Universiteit Amsterdam, De Boelelaan 1085, $1081 \mathrm{HV}$ Amsterdam, the Netherlands

\section{Abstract}

\section{Purpose of Review:}

Understanding of how fire affects the carbon cycle and climate is crucial for climate change adaptation and mitigation strategies. As those are often based on Earth system model simulations, we identify recent progress and research needs that can improve the model representation of fire and its impacts.

\section{Recent Findings}

New constraints of fire effects on the carbon cycle and climate are provided by the quantification of the carbon ages and effects of vegetation types and traits. For global scale modelling the low understanding of the human-fire relationship is limiting.

\section{Summary}

Recent developments allow improvements in Earth system models with respect to the influences of vegetation on climate, peatland burning and the pyrogenic carbon cycle. Better understanding of human influences is required.

Given the impacts of fire on carbon storage and climate, thorough understanding of the effects of fire in the Earth system is crucial to support climate change mitigation and adaptation.

Keywords: Fire, carbon cycle, climate, peatlands, pyrogenic carbon, vegetation traits.

\section{Introduction}

Climate change mitigation strategies rely heavily on carbon storage in forests [1] and therefore require understanding of the interactions between fire, vegetation and the carbon cycle. 
Interactions of fire with the carbon cycle and climate were conceptually understood and described decades ago [2, 3].

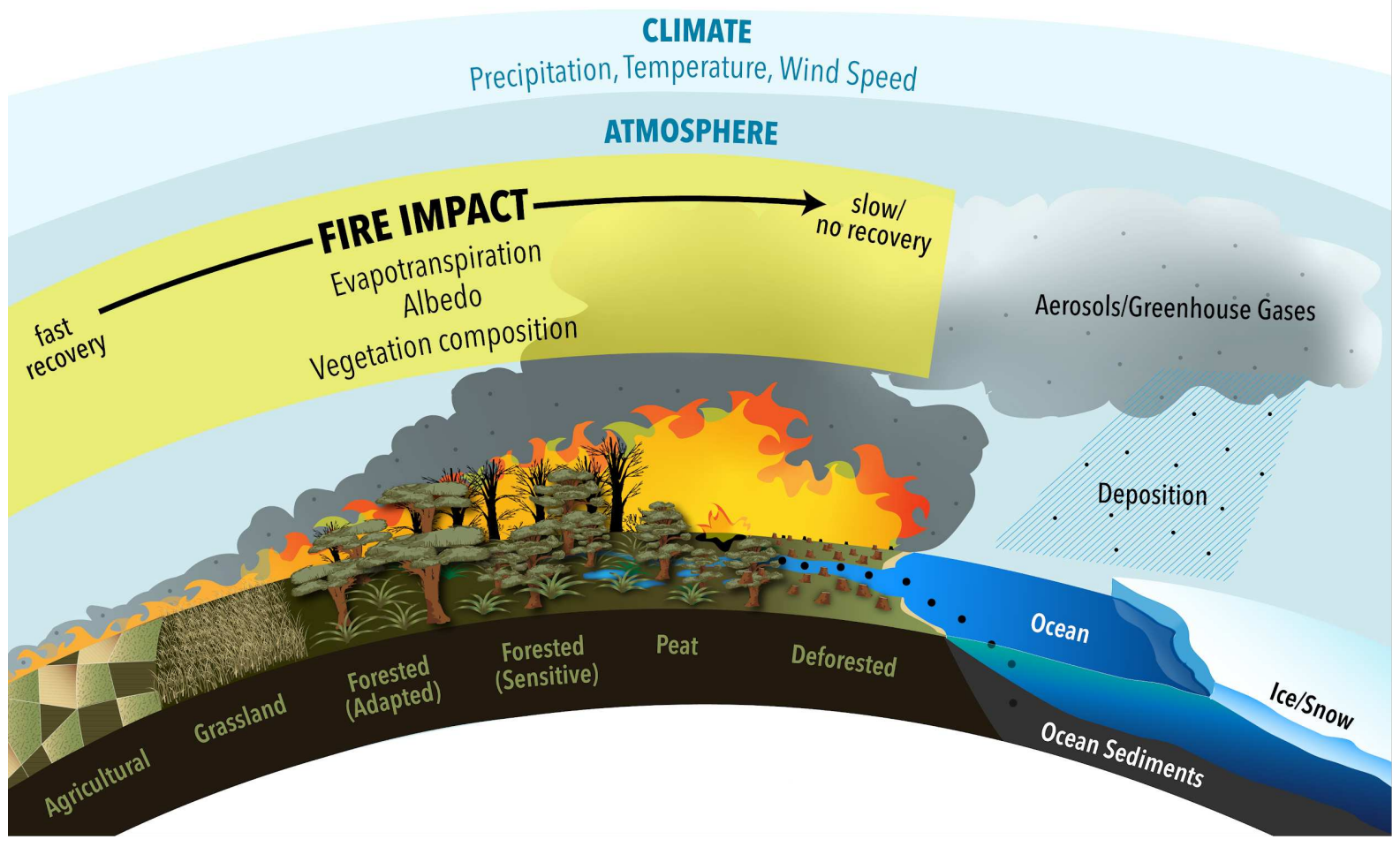

Figure 1: The impact of fire on carbon cycle and climate differs between ecosystems. Fire changes land surface properties and energy fluxes, such as vegetation composition, albedo and evapotranspiration. All of these aspects influence the atmosphere. A key aspect is the ability of the system to recover to a pre-fire state. Grasslands and forest with fire adapted traits recover faster than forests that are sensitive to fire or peatlands which lose old carbon. Deforestation fires lead to a long-term reduction of aboveground biomass. The gases and particles emitted during a fire increase the levels of atmospheric greenhouse gas concentration and aerosol load, with consequences for radiative transfer and cloud formation. In contrast recalcitrant pyrogenic carbon can accumulate in soil for decades to century timescales and even millennia in ocean sediments, thus offsetting the carbon source effect.

The combustion of vegetation biomass leads to a reduction of terrestrial biomass and impacts vegetation patterns [4]. The consequences are an overall reduction of carbon stored on land and emissions of various trace gases and aerosols [5]. The incomplete combustion of biomass, however, also generates charcoal (pyrogenic carbon, $\mathrm{PyC}$ ) which is relatively stable, thus partly offsetting the carbon source effect of fire emissions as it accumulates in soils and sediments over decadal to century timescales [3]. Fire alters nutrient cycles, such as the nitrogen [6] or phosphorus cycle [7], thereby limiting vegetation productivity in regions with high losses of nutrients and increasing productivity due to fertilization in areas of deposition. Fire emissions substantially influence the atmospheric budgets of greenhouse gases, other trace gases and aerosols [8]. Aerosols influence the radiation budget by scattering and absorbing radiation. They increase the number of cloud condensation nuclei which changes cloud cover, precipitation and cloud albedo through cloud microphysics [2]. However, aerosol effects on climate are still associated with large uncertainties [9, 10]. Fire emissions influence atmospheric chemistry and trigger reactions that influence the lifetime of methane and increase ozone concentration, air pollution levels and acid deposition with side effects on vegetation $([2,3])$. 
The effects of fire on vegetation dynamics and land surface properties impact the carbon cycle but also the climate through biogeophysical effects [11] (figure 1). Vegetation dynamics govern the time scale of carbon pools recovery but also influence land surface properties such as evapotranspiration and albedo, due to differences between vegetation types (grasses vs. woody) and species [12]. These differences are for instance the development of fire adaptation traits, or the ability of quick resprouting [11].

Satellite-observed fire occurrence and emissions data products provide the backbone for a large variety of research over the recent decade. For instance, fire emission datasets can serve as input to atmospheric models to improve the understanding of effects of fire emissions on atmospheric composition and climate [5]. Burned area products are used to understand drivers of fire occurrence and to develop and evaluate global fire models [13]. The representation of fire in global vegetation but also Earth system models has been improved during the last two decades [13, 14]. These models allow us to extrapolate fire occurrence and their impacts to periods without observations and take into account interactions between fire, carbon cycle and climate. So far, the most complete assessment used an Earth system model to estimate the radiative forcing of fires for past, present and future and found an overall cooling effect of fires on climate [5]. The cooling is largely driven by the highly uncertain indirect aerosol cooling effect, which overrides the warming effect by fire greenhouse gas emissions.

We here summarize recent progress in understanding and estimating the impact of fire on the carbon cycle and climate. We focus on research that provides large scale assessments of the impacts of fire or helps to improve the representation of fires within Earth system models. We summarize recent model assessments of the impact of fire. We identified progress in process understanding over the last five years especially concerning the effect of vegetation type and traits on climate, peatland fires, and the pyrogenic carbon cycle. Finally we summarize progress in observational datasets that help to constrain and develop models. We conclude by summarizing where we see the greatest potentials and needs for improvements in the representations of fires in Earth system models.

\section{Modelled impacts of fire on the carbon cycle}

Modelling fire in global models is a relatively young field [13]. A recent evaluation of fire models within the fire model intercomparison project [15] shows that the influence of climate on fire occurrence is reasonably well captured by models but the relationship between fire and vegetation productivity needs further refinement [16]. Models represent the influences of fire on the carbon cycle and climate in a numeric way and can therefore quantify the net effect of fire on the different components and parameters by performing simulations with and without fires. Several models have conducted such simulations over the recent years with diverging results [17-20]. Models either prescribed the burned area based on remote sensing datasets $[19,20]$ or simulate a similar global burned area, since remotely sensed burned area is typically used for model calibration $[17,18]$. In Li et al. [17] fire was found to decrease the land carbon uptake by $1 \mathrm{Pg} \mathrm{year}^{-1}$ and it decreases NPP by 1.9 $\mathrm{Pg}$ year $^{-1}$ [17]. In the ORCHIDEE model, fires reduce the terrestrial carbon uptake by only $0.32 \mathrm{Pg}$ $\mathrm{C}$ year $^{-1}$ [18]. Yue et al. [18] trace the origin of this to a lower impact on vegetation productivity because the impact on vegetation structure was limited due to a prescribed tree height. The coupling of fire within these vegetation models was incomplete because the studies did not account for the effect of fire on vegetation cover. This is important because vegetation type and structure strongly determines the biomass storage on land [1]. Poulter et al. [19] estimate the impact of fire prescribing three different burned area satellite products. In this study fire led to decreases in 
forested area, but grasses were more productive such that the net effect of fire was an increase in NPP of 0.7-5.2 Pg C year ${ }^{-1}$ and a small increase in net biome production 0.05-0.11 Pg C year ${ }^{-1}$. Total biomass decreased between 50 and $300 \mathrm{PgC} \mathrm{year}^{-1}$ due to the losses in woody covered area. In a similar study [20] using a different model but the same setup as Poulter et al. [19], forests were more productive, therefore the decrease in forested areas due to fire decreased NPP by $4 \mathrm{Pg} C$ year

${ }^{1}$. Reduction in heterotrophic respiration was stronger than the reduction in NPP, causing an increase in net ecosystem production due to fire. In combination with the fire emissions this lead to a decrease of the land sink of $0.57 \mathrm{Pg} C$ per year $\left.{ }^{-1}[20]\right)$.

The impact of fire on the land sink varies between years because of variations in climate, with a stronger reduction found in warm and dry years [18]. Fire leads to net losses of carbon during the fire. During the recovery time of vegetation and carbon stocks following the fire, the ecosystem accumulates carbon, until equilibrium is reached or the next fire incidence occurs. In savanna ecosystems the feedback between fire and vegetation can lead to a permanent shift of the equilibrium to an alternative stable state [21]. Global models were often criticized to not include such dynamics [22]. A recent study showed that it is possible to achieve such dynamics with a relatively simple global vegetation model [23]. In the boreal system where the recovery is slow the present day spatial distribution of carbon sinks is therefore driven by fires that occurred over the last decades [24]. The net effect of fire critically depends on the balance of legacy sinks caused by vegetation recovery from past fires and emissions of current-day fire disturbances, e.g. changes in the fire regime. However, it is necessary to point out that most of these studies, if not all, were performed with models that do not account for the pyrogenic carbon component or losses due to peat fires, which likely make a strong contribution to the net effect.

Fire affects the carbon cycle directly but also releases nutrients and air pollutants that can affect vegetation. Nutrients, most importantly nitrogen and phosphorus, strongly determine vegetation productivity. Nitrogen losses due to fire are an important part of the nitrogen balance regionally [25]. Losses at the site are important, but also the deposition in other regions: high atmospheric nitrogen deposition rates were observed on a field site in the central Congo Basin where due to its remoteness, a low nitrogen deposition from any industrial sources is expected [26]. Using atmospheric models the authors attributed the source of this increased deposition predominantly to fire. Phosphorus availability limits plant productivity and enhances the marine biological pump. Natural fires contribute an estimated $20 \%$ to global phosphorus emissions [27], this new estimate of the contribution is ten times higher than a previous estimate [27]. Increased atmospheric ozone concentration due to air pollution by fire emissions, however, leads to plant damages and reduction in vegetation productivity. This effect was quantified with a model for the Amazon forest [28] and boreal North America [29]. In the Amazon forest ozone damage could double the effect of wildfires on carbon storage [28]. For North America the effect of ozone was negligible, but aerosol effects resulted in enhanced air stability and intensified regional drought. This effect increased NPP for present day by $72 \mathrm{TgC}_{\text {year }}{ }^{-1}$ but would decrease NPP by $118 \mathrm{TgC}$ year ${ }^{-1}$ in 2050 . Few studies have accounted for this influence of fire on the redistribution of nutrients or the feedback with ozone production. These recent studies elucidate the importance of these processes. To account for these effects, a coupled land-atmosphere modelling approach is required.

The trends in burned area are spatially heterogeneous [27]. For the global burned area a decreasing trend was detected between 1998 and 2015, mainly due to decreases in savanna regions [27]. The decreases are related to an increased intensity in land management. Global fire models require a better representation of the global variability in human effects to improve modelled trends in burned area [30]. The level of understanding how humans use fire in land management is still 
unsatisfactory and no global spatially explicit dataset on how humans use fire in land management exists [31]. Model results reflect this low level of understanding and show contrasting results due to different assumptions. A model that included management fires, such as cropland and deforestation fires showed decreases in the carbon sink over the $20^{\text {th }}$ century due to the anthropogenic influence [32]. In contrast, a model accounting only for fires in natural vegetation showed increases in carbon uptake due to the reduction in global burned area [33]. The satellite record is relatively short and robust trends are often not statistically significant [30]. The human impact on burned area in a global model varies strongly between regions and is highest for intermediate vegetation productivity [34]. The global representation of humans within models is uncertain, the study [34] however showed that interactions with vegetation and the carbon cycle, for instance due to land use change, need to be taken into account to quantify the effects of humans on burned area. Representation of the anthropogenic effects will be a major challenge for reliable future projections. Given the large uncertainty in understanding, a model ensemble representing a variety of assumptions on anthropogenic effects can help to cover the possible trajectories of future fire occurrence and impacts. Model intercomparison projects can provide the infrastructure to support such research and is already in place for global fire-enabled vegetation models.

\section{Modelled impacts of fire on climate}

Fires influence atmospheric composition directly by emissions of greenhouse and other trace gases and aerosols. An atmospheric modelling study suggested that the aerosol effect overrides the greenhouse gas effect and leads to a net reduction in the global radiative forcing of fires [5]. Landry et al. [35] examined the global effects of aerosols only, and found a present-day forcing of $-0.10 \mathrm{~W}$ $\mathrm{m}^{-2}$, which affected regional land carbon stocks on decadal timescales through changes in vegetation productivity and soil-litter decomposition. Jiang et al. [36] used atmospheric modelling with prescribed present-day fire aerosol emissions (including agricultural burning) and found that fires exert a direct radiative effect of $0.16 \pm 0.01 \mathrm{Wm}^{-2}$ (primarily due to black carbon) and an indirect effect due to aerosol-cloud interactions of $-0.70 \pm 0.05 \mathrm{~W} \mathrm{~m}^{-2}$, supporting the finding of Ward et al. [5] that indirect effects dominate. In contrast to Ward et al. [5], Jacobson [37] found a net warming of $0.4 \mathrm{~K}$ accounting for black and brown atmospheric carbon, heat and moisture fluxes and cloud absorption effects. This, however, also included domestic sources and therefore is not directly comparable to the aforementioned estimates focusing on wildfires only. In addition to its long-term influence on climate, fire is also the major driver of interannual variability in global aerosol abundances and their radiative forcing $[8,38,39]$.

The effects of aerosols are spatially heterogeneous. Local effects of aerosols are extensively documented in the literature using models and observational data. Aerosols increase the number of cloud condensation nuclei. This leads to a reduced droplet size and in consequence a reduction of rainfall. A rainfall reduction has been documented for South America [40] and southern Africa [41]. Furthermore, satellite information has shown that fire causes reductions in cloud cover over Africa [42]. Voulgarakis and Field [8] provide a more extensive review on effects of fire on aerosols and other short-lived pollutants, as well as associated influences on climate.

The quantification of fire emissions is still a major uncertainty for modelling atmospheric aerosol loads. Testing input datasets for Earth system modelling identified fire emissions as the largest source of uncertainty in pre-industrial aerosol emissions [43]. Most global atmospheric models underestimate fire aerosol optical depths when using bottom-up estimates of fire aerosol emissions, necessitating the application of large scaling factors to regional or global emissions within the 
models $[5,44]$. Model process representation, such as treatment of aerosol hygroscopicity [45], could also be contributing to this discrepancy which is a major cause of uncertainty in model estimates of aerosol effects. For present day, Veira et al. [46], investigated the effect of emission heights, showing that the quantification of emissions leads to larger differences in the radiative forcing than the parameterization of the emission heights of fires. Under climate warming, more intense fires and therefore increases in emission heights and atmospheric residence times of emitted pollutants are expected. In an Earth system model the effect of more intense fires was mitigated by a more stable atmosphere and led only to small changes in emission heights and long range transport [47].

There is a large uncertainty for the aerosol indirect forcing [48], and only Ward et al. [5] have investigated the multi-component radiative forcing from fire until now. A systematic comparison of coupled models could help to identify uncertain model assumptions and support model development.

Li et al. [49] estimated the biogeophysical effects of fire on climate for present day using an Earth system model. The model setup affected vegetation structure, e.g. leaf area index, but not the vegetation composition. Effects of greenhouse gases or aerosols emitted by fires were not included. Vegetation cover was the main pathway through which fire influenced the climate. Tropical savannas were the regions with the strongest impacts of fire. Fire reduced vegetation canopy and height. This change in structure resulted in drier, warmer surface air and higher wind speed due to changes in the energy partitioning and surface roughness. Fire-induced damage to the vegetation canopy increased the temperature by reducing the latent heat flux. Earth system models represent the variability in vegetation types through plant functional types (PFTs) with PFT specific parameters, they, however, currently do not represent the nuanced picture of vegetation and trait-specific fire influences observed by satellites and described below.

\section{Improved understanding of fire-induced vegetation effects on climate}

Vegetation traits not only determine the resilience and flammability of vegetation and carbon stocks but also drive the impact on climate, as differences in vegetation and fire regime define the differences in the response of surface properties to fire $[11,50]$. A continental analysis of satellite data for North America confirms that in addition to climate, vegetation type and fire severity determine the recovery time of vegetation [51]. The effect of fire type on its impact on climate was investigated for Eurasia: for high intensity stand replacing fires, in which most trees do not survive, albedo increases [52] which causes a strong cooling effect. For non-stand replacing fires this effect was weak [53]. The difference between stand replacing and non-stand replacing fires is caused by the different effects of snow on the albedo between non-forested and forested areas and snow cover remains longer on non-forested areas in spring. The albedo increase is much higher on grasslands as forest canopies are usually not completely covered by snow. The net response of land surface temperature to fire in boreal Siberian forests was a warming one year after fire; a cooling in winter was exceeded by a summer warming [54]. The strength of the response differed between vegetation types, with stronger effects for evergreen needleleaf forests [54]. An investigation of intercontinental differences in boreal fire regimes and their climate impacts showed that boreal fires in Eurasia were, less intense, resulting in less tree cover loss, and reduced albedo change [50]. This implies that both warming (through greenhouse gas emissions), and cooling (through post-fire albedo) effects are larger for boreal fires in North America compared to Eurasian boreal fires. The 
main driver of this continental difference in boreal fires and their climate impacts is the difference in vegetation composition and plant traits. Fire embracers, such as black spruce and jack pine, dominate boreal North America. They promote high intensity crown fires as they retain low-lying branches and they cope with fire with adapted reproduction, e.g. serotinous cones or seed banks. Fire resisters support low intensity fires through self-pruning and lower flammability. They are dominant in boreal Eurasia, mainly (Scots Pine and larch). This case study [50] exemplifies that within-biome differences in fire strategies result not only in different fire regimes but also in different climate impacts. Liu et al. [55] perform a global analysis of satellite data on the biophysical feedback of forest fires on surface temperature. They find strong differences between the boreal and tropical biome. The boreal regions show a long-term cooling effect due to changes in albedo, while the tropical regions show a weaker warming effect due to reduced evapotranspiration.

Climate- and fire-induced effects on vegetation may also be coupled. This increases the complexity of the necessary process understanding. For example, climate warming has increased deep burning in organic soils of boreal conifer forests [56]. Deciduous tree recruitment is favored after deep burning and exposure of mineral soils [57], and likely partly enhanced by warming as well. An ecosystem shift from conifer-dominated to deciduous-dominated landscapes may thus be the consequence. Such a shift has important implications for terrestrial carbon storage and land surface albedo [58]. Deciduous trees in Alaskan ecosystems such as aspen and birch store more aboveground carbon than black spruce trees [59], but significantly less belowground carbon. For this reason, type conversion towards deciduous dominance may represent a net carbon source. Deciduous trees are, however, brighter than conifer trees, resulting in an albedo-driven cooling effect. Similarly, combined climate- and fire-induced expansion of woody species into areas that were tundra before would result in albedo darkening and would thus lead to a warming effect. Veraverbeke et al. [60] hypothesized that this feedback loop may also bring more lightning ignitions to the ecotone between the boreal forest and tundra, which would further amplify this feedback loop.

\section{Improved understanding of peatland fire and pyrogenic carbon}

The net effect on carbon storage of a fire is determined by the ecosystem ability to recover the combusted carbon stocks and the fate of the combusted carbon. Large parts of the carbon losses from fire are restored as vegetation regrows and the fire-induced reduction of carbon stocks also lowers carbon losses due to respiration $[18,20]$. However, peatland, deforestation and degradation fires usually have a net loss effect. Peatlands are important terrestrial carbon reservoirs that have acted as carbon sinks throughout most of the Holocene $[61,62]$. Consequently, carbon stored in peatlands has not been part of the active carbon cycle for the last centuries to millennia [63]. Following deforestation and degradation fires, vegetation and soil carbon stocks often do not recover to their pre-fire level. The combusted carbon can either be lost to the atmosphere or accumulate in terrestrial or oceanic systems through the production of highly stable solid pyrogenic carbon (or charcoal, PyC) [64]. PyC was early on recognized as an important recalcitrant by-product of wildfires, which can support the terrestrial carbon sink [3].

Peatlands cover only $3 \%$ of the land surface, but contain a third of the carbon stored in soils [65]. Arctic-boreal peatlands contain an estimated $500-600 \mathrm{Gt}$ carbon, with $90 \%$ being stored in permafrost regions [66]. Tropical peatlands additionally store approximately $100 \mathrm{Gt}$, mostly in Southeast Asia [63, 65]. Carbon emissions per burned area from peatland fires are among the highest on Earth [44]. An important characteristic of the carbon stored in peatlands is its age, which indicates how long it took 
to accumulate this carbon stock. Wiggins et al. [67] estimated a mean turnover time of 800 years ( \pm 420 years) for the carbon burned in Indonesia. Wilkinson et al. [68] estimated the loss of carbon in a boreal peatland fire as being equivalent to $240-860$ years of carbon accumulation.

Peatland fires not only lead to losses of carbon but also interact with other ecosystem processes, for example hydrological processes. Peatland fires may additionally increase the vulnerability of peatlands due to ecosystem degradation and desiccation $[69,70]$. Many boreal fires and all arctic fires occur in permafrost terrain [71]. Fires remove parts of the insulating soil organic layer, resulting in permafrost degradation, loss of peat plateau and deepening of the seasonally thawed active layer above the permafrost [71]. This is associated with increases of microbial soil respiration of $\mathrm{CO}_{2}$ and $\mathrm{CH}_{4}$ [72]. Post-fire boreal forest soils typically are a longer-term $\mathrm{CO}_{2}$ source because of decomposition of organic matter and root respiration, and a $\mathrm{CH}_{4}$ sink because of microbial oxidation [72, 73]. The warming effect from the $\mathrm{CO}_{2}$ source is much stronger than the $\mathrm{CH}_{4}$ sink cooling effect [72]. Peatland fires are also a major source of atmospheric short-lived species such as carbon monoxide, nitrous oxides and aerosols, being the dominant type of fires that drive the variability of these species in the atmosphere $[8,39]$.

Peatland fires are so far only included in a diagnostic way in global models [74, 75]. This allows the estimation of fire emissions from peatlands, but the changes in carbon storage on land, which would require to model losses but also the uptake of carbon, are not tracked.

Up to $27 \%$ of burned carbon is retained as Pyrogenic carbon from wildfires rather than emitted to the atmosphere as greenhouse gases, while anthropogenic fossil fuel derived $\mathrm{PyC}$ is a minor contribution ( $0.2 \%$ of emissions) [64]. PyC characteristics depend on the source material, combustion temperature and duration and cover a diverse range in chemical and physical properties from charcoal to soot [76]. Over the recent years substantial progress has been achieved in quantifying the individual fluxes, stocks, and ages of pyrogenic carbon $[64,77]$. Field observations indicate a global PyC production of 114-383 $\mathrm{TgC}$ year ${ }^{-1}$ [64]. Only a fraction of this is however stored in long-term reservoirs [78]. Mainly rivers transfer PyC from terrestrial pools to the oceans [76, 79] and a fraction of $8-16 \%$ of the annual PyC production is buried in marine sediments [80]. Ages of particulate river PyC range from modern up to 17,000 14C yrs [81]. The average river particulate PyC age is $3,700 \pm 40014 \mathrm{C}$ yrs, suggesting aging on land by delaying PyC release to the oceans [81, 82]. Meanwhile, the oldest $\mathrm{PyC}$ pools are in the ocean water where observed ages are on the order of $23,000{ }^{14} \mathrm{C}$ yrs [83]. Reconciling these large differences in ages is challenging due to large knowledge gaps with respect to the mobilization and transportation of $\mathrm{PyC}$ from land to ocean $[76,84,85]$. Understanding the pyrogenic carbon cycle becomes particularly important as the addition of biochar to soils is part of negative emission technologies to mitigate climate change [86].

Robust constraints on the role of $\mathrm{PyC}$ in regional and global scale carbon cycle remains elusive due to limitations in characterization, and related uncertainties in the fluxes and fate of PyC during transfer from land to ocean. When covering the uncertainties of parameters in a model representation of the pyrogenic carbon cycle, $\mathrm{PyC}$ can either be a sink or source of carbon over the 21st century for most scenarios [87]. Landry and Matthews [87] estimate the sink as the difference between a simulation including a PyC pool compared to a simulation directly emitting that carbon as $\mathrm{CO}_{2}$. While this gives an estimate of how important it is to account for the longer residence times of $\mathrm{PyC}$, it does not answer the question whether the total effect of fire in Earth history (including the generation of PyC) is a net carbon sink or source. This would require the comparison of equilibrium simulations with and without fire. In models not accounting for longer residence times of $\mathrm{PyC}$ the losses of terrestrial carbon storage due to fires are $50-500 \operatorname{PgC}[5,19]$. The estimates of the losses of terrestrial carbon storage do however not include peatlands, which could be substantial. Global estimates of PyC storage exceed these values already when only accounting for the two largest stocks (480-1140 PgC in marine sediments [77] and $200 \mathrm{PgC}$ in soils [78]. This indicates that PyC storage may exceed the 
losses in terrestrial carbon storage and therefore the total effect fire over the last millenia could be a net sink of carbon. There is, however, also support for a positive carbon cycle climate feedback based on charcoal data. Harrison et al. [88] estimate a substantial contribution of increased biomass burning to the carbon-cycle-climate feedback $\left(5.6 \pm 3.2 \mathrm{ppm} \mathrm{CO}_{2}\right.$ per degree of land temperature). This study however refers to timescales of decades and centuries. The net effect of fire on the carbon cycle thus remains an open question.

\section{Improvements in observational datasets}

Observational datasets are the main source of information to develop process understanding and to evaluate models. The first step towards assessing the impacts of fire is estimating the global extent of fire occurrence. Remote sensing is the only way to consistently observe fire-affected areas and timing on a global scale. In remote sensing products fire occurrence is usually represented as burned area [89, 90], fire counts [91] or fire radiative power [92]. The most widely burned area detection algorithms use fire-induced changes in surface reflectance (caused by vegetation removal and soil and charcoal exposure). Large parts of a pixel need to be burned to be detected as burned. These moderate resolution burned $(500 \mathrm{~m})$ area products $[89,90]$ are therefore suboptimal to detect small fires. Active fire algorithms require only that approximately 1 to $10 \%$ of the pixel area actively burns to be detected [93]. Including information on active fires therefore improves the detection of small fires [94]. For the most recent MODIS (Moderate Resolution Imaging Spectroradiometer) Collection 6 data set version the enhanced detection of small fires resulted in a global increase of burned area of $26 \%$ [89]. Higher resolution satellite data from Landsat $(30 \mathrm{~m})$ and Sentinel-2 $(20 \mathrm{~m})$ can improve the detection. They were increasingly used in regional studies. Landsat imagery was used to map burned area in Australia [96], Canada [97], and the conterminous USA [98]. The combination of active microwave data from Sentinel-1, which observes the land surface regardless of clouds, with reflectance data from Sentinel-2 showed promising results for burned area mapping in Congo [99]. Sentinel-2 data were recently used to generate a burned area dataset for sub-saharan Africa [100].

Recently, Laurent et al. [101] and Andela et al. [102] developed databases with fire regime parameters such as fire ignition, size, or fire spread rate. These databases open new possibilities for more comprehensive understanding of the relationship between fire occurrence, fire behaviour and fire impact. Their approaches group individual burned pixels into a fire patch based on the continuity of their detected dates of burning. Laurent et al. [101] released the FRY database, a global database of fire patches with morphology-based functional traits, derived from the Collection 6 MCD64A1 and MERIS fire_cci v4.1 burned area data. They examined the global distribution of and relationships between various fire patch parameters such as fire size, patch perimeter to area ratio, patch shape index and patch fractal correlation dimension. In parallel, Andela et al. [102] published the Global Fire Atlas, in which they not only made the fire patch reconstruction but also calculated fire duration, daily fire front length, daily fire area expansion, fire spread rate and the direction of spread.

Progress has been made in observing details of peat burning. Advances from remote sensing observations over the September-October 2015 Indonesia fires come from high resolution burned area mapping with Sentinel-1 imagery [103] and high resolution fire detection and spread mapping using mid infrared data from the FireBird mission [104]. In the boreal region the depth of burns in peatlands was mapped from height information from airborne LiDAR $[105,106]$ and photogrammetric unmanned aerial vehicle systems [107]. Laboratory and in situ observations lead to detailed characterizations of the controls of moisture content and bulk density on horizontal [108] and 
downward spread [109], and combustion [110, 111]. These details will be highly useful to develop models of peatland burning.

Improvements in emission estimates over the last years were based on improved estimates of fuel loads, combustion completeness and emission factors. Improvements of these estimates were achieved based on a larger variety of and advances in measurements, both from an in situ and remote sensing perspective. For example, synergetic use of hyperspectral and light detection and ranging (LiDAR) imagery has led to advances in fuel type [112] and post-fire effects mapping [113]. A global database [114] provided an improved basis for model parameterization of combustion completeness. Several field campaigns have acquired additional measurements of in situ combustion in North America's boreal regions (e.g. $[115,116])$. Emission factors determine the separation of emissions into the different chemical species. Wiggins et al. [117] estimated $\mathrm{CO}$ and $\mathrm{CH}_{4}$ emission factors of boreal fires in Alaska by integrating flux tower measurements, remote sensing data and air transport modeling. Their approach has potential to derive emission factors for a wide range of environmental conditions. Currently emission factors used in fire emissions databases and models are constants specified for a variety of ecosystems [15, 44].

While spaceborne data provide detailed spatiotemporal information of contemporary fire dynamics, charcoal records indicate the variations in biomass burning over long time scales (decades to millenia). Charcoal records are harmonized in a global database [118] and are extensively used to investigate drivers of fire occurrence. However, the information cannot be directly transferred to quantities of burned areas or fire emissions, which has limited their use in carbon cycle studies so far. The variability in the charcoal records however compares well with methane-derived past fire activity, which increases the confidence in this dataset [88]. In recent dataset developments, charcoal records were combined with satellite based estimates, airport visibility data and fire model output to generate a dataset of fire emissions since 1700 [119]. Calibration studies that link charcoal variability to satellite burned area or fire emission datasets can improve the potential of this dataset to inform carbon cycle studies [118].

\section{Conclusions}

Due to the linked interactions of fire with climate, the carbon cycle and vegetation, fire is a necessary component within Earth system models. Vice versa, the assessment of the global impact of fire on the carbon cycle and climate requires Earth system models. Vegetation dynamics, different residence times between different carbon stocks and aerosol effects are critical to address the overall impact of fire. So far no model includes all the effects that are of known importance. In Table 1 we provide an assessment of our current levels of process understanding, available observations and incorporation of these processes in global models.

Improvements in modelling the impact of fires are possible based on recent advances. We identified the need, but also the progress in understanding, for an improved representation of fire within Earth system models with respect to the pyrogenic carbon cycle and peatlands. Pyrogenic carbon and peatlands are both usually not represented in fire models $[13,14]$ (Table 1). Understanding the pyrogenic carbon cycle is certainly important for understanding the net impact of fire within the Earth system due to the large stocks in ocean sediments. The importance of understanding the pyrogenic carbon cycle may increase even on shorter time scales as it may be subject of strong human perturbations due to the use of biochar in climate change mitigation actions. There is progress in understanding peatland fires and peatlands are increasingly represented within Earth system models. The coupling of fires and peatlands may therefore become a new, promising research field within Earth system modelling. Interactions between fire, peatlands and permafrost 
are still insufficiently understood. Overall, models show a large divergence in their estimates of the impact of fire on the carbon cycle. Better understanding of the reasons for the differences in combination with model-data comparisons will facilitate the decision on the best model structures and assumptions $[13,15]$.

Table 1: Assessment of the level of process understanding, availability of observations and incorporation into models.

\begin{tabular}{lccc} 
Process & $\begin{array}{l}\text { Process } \\
\text { Understanding }\end{array}$ & $\begin{array}{c}\text { Availability of } \\
\text { Observations }\end{array}$ & $\begin{array}{c}\text { Incorporation into } \\
\text { Models }\end{array}$ \\
\hline Biomass consumption & 0 & 0 & 0 \\
Peatland fire & 0 & 0 & 0 \\
Pyrogenic carbon & 0 & 0 & 0 \\
Deforestation fire & 0 & 0 & 0 \\
Vegetation type impact on: & & & 0 \\
-Carbon storage & 0 & 0 & 0 \\
-Albedo & 0 & 0 & 0 \\
-Evapotranspiration & 0 & 0 & 0 \\
Redistribution of nutrients & 0 & 0 & 0 \\
Human-fire interactions & 0 & 0 & 0
\end{tabular}

Aerosol impact on:

\begin{tabular}{|c|c|c|c|}
\hline -Radiation & 0 & 0 & 0 \\
\hline -Clouds & 0 & 0 & 0 \\
\hline Greenhouse gases & 0 & 0 & $\mathbf{0}$ \\
\hline Level of & $\begin{array}{l}\text { Process } \\
\text { Understanding }\end{array}$ & $\begin{array}{l}\text { Availability of } \\
\text { Observations }\end{array}$ & Incorporation into Models \\
\hline 0 & $\begin{array}{l}\text { Limited } \\
\text { understanding }\end{array}$ & Low or scarce & Only individual models \\
\hline 0 & $\begin{array}{l}\text { Qualitative } \\
\text { understanding }\end{array}$ & $\begin{array}{l}\text { Uncertain but } \\
\text { global coverage } \\
\text { or good quality } \\
\text { but not global }\end{array}$ & $\begin{array}{l}\text { Included but } \\
\text { parameterization } \\
\text { very uncertain }\end{array}$ \\
\hline $\mathbf{0}$ & $\begin{array}{l}\text { Quantitative } \\
\text { understanding }\end{array}$ & $\begin{array}{l}\text { High quality with } \\
\text { global coverage }\end{array}$ & $\begin{array}{l}\text { Usually included in global } \\
\text { models }\end{array}$ \\
\hline
\end{tabular}


The fire effects that are realized through changes in vegetation require coupled modelling as does the effects of nutrients redistribution and the ozone and aerosol feedback on the vegetation productivity. Knowledge on the climate impacts through vegetation changes has strongly improved and should be included in coupled modelling. While there is already an international initiative for a systematic comparison of fire-enabled vegetation models [13, 15], it does not yet exist for coupled vegetation-atmosphere models. This could certainly help to assess the uncertainties in model representation and to identify necessary improvements in representing fire-Earth system interactions.

Earth system models provide an important tool for the development of climate change adaptation and mitigation strategies. In this context, the impact of humans on fire is a critical factor for modelling changes in fire regimes and fire-induced impacts on carbon storage and climate in the future. A thorough understanding of the role of fire within ecosystems and its multifaceted impacts on climate is therefore needed to reduce uncertainties in future Earth system projections and understand the potential role of fire management for climate change adaptation and mitigation.

\section{Acknowledgements}

We acknowledge feedback and suggestions on the manuscript from Fang Li and Daniel Ward, the editor and two reviewers.

\section{Funding}

Gitta Lasslop acknowledges funding from the German research foundation. Sander Veraverbeke acknowledges support from the Netherlands Organisation for Scientific Research (NWO) through his Vidi grant 'Fires pushing trees North'. Alysha Coppola acknowledges funding from the University of Zurich For Forschungskredit post-doctoral fellowship. Chao Yue acknowledges the support from the China One Thousand Youth Programme.

Human and Animal Rights. This article does not contain any studies with human or animal subjects performed by any of the authors.

Conflict of Interest On behalf of all authors, the corresponding author states that there is no conflict of interest.

\section{References}

Bullets indicate important $(\bullet)$ or very important $(\bullet \bullet)$ recent references (within past $\mathbf{3}$ years) with brief explanations of their importance.

1. Grassi G, House J, Dentener F, Federici S, den Elzen M, Penman J (2017) The key role of forests in meeting climate targets requires science for credible mitigation. Nat Clim Chang $7: 220-226$

2. Crutzen PJ, Andreae MO (1990) Biomass burning in the tropics: impact on atmospheric chemistry and biogeochemical cycles. Science 250:1669-1678

3. Seiler W, Crutzen PJ (1980) Estimates of gross and net fluxes of carbon between the biosphere and the atmosphere from biomass burning. Climatic Change 2:207-247 
4. Bond WJ, Woodward FI, Midgley GF (2005) The global distribution of ecosystems in a world without fire. New Phytol 165:525-537

5. Ward DS, Kloster S, Mahowald NM, Rogers BM, Randerson JT, Hess PG (2012) The changing radiative forcing of fires: global model estimates for past, present and future. Atmospheric Chemistry and Physics 12:10857-10886

6. Chen Y, Randerson JT, Van Der Werf GR, Morton DC, Mu M, Kasibhatla PS (2010) Nitrogen deposition in tropical forests from savanna and deforestation fires. Glob Chang Biol 16:2024-2038

7. Mahowald NM, Artaxo P, Baker AR, Jickells TD, Okin GS, Randerson JT, Townsend AR (2005) Impacts of biomass burning emissions and land use change on Amazonian atmospheric phosphorus cycling and deposition. Global Biogeochem Cycles. doi: 10.1029/2005GB002541

8. Voulgarakis A, Field RD (2015) Fire influences on atmospheric composition, air quality and climate. Curr Pollution Rep 1:70-81

9. Bowman DMJS, Balch JK, Artaxo P, et al (2009) Fire in the Earth system. Science 324:481484

10. Landry J-S, Matthews HD, Ramankutty N (2015) A global assessment of the carbon cycle and temperature responses to major changes in future fire regime. Climatic Change 133:179192

11. Archibald S, Lehmann CER, Belcher CM, et al (2018) Biological and geophysical feedbacks with fire in the Earth system. Environmental Research Letters 13:033003

12. Randerson JT, Liu H, Flanner MG, et al (2006) The impact of boreal forest fire on climate warming. Science 314:1130-1132

13. Hantson S, Arneth A, Harrison SP, et al (2016) The status and challenge of global fire modelling. Biogeosciences 13:3359-3375 • This paper provides an overview of global modelling approaches and their history.

14. Kloster S, Lasslop G (2017) Historical and future fire occurrence (1850 to 2100) simulated in CMIP5 Earth System Models. Glob Planet Change 150:58-69

15. Rabin SS, Melton JR, Lasslop G, et al (2017) The Fire Modeling Intercomparison Project (FireMIP), phase 1: experimental and analytical protocols with detailed model descriptions. Geosci Model Dev 10:1175-1197

16. Forkel M, Andela N, Harrison SP, et al (2018) Emergent relationships on burned area in global satellite observations and fire-enabled vegetation models. Biogeosciences Discussions $1-31$

17. Li F, Bond-Lamberty B, Levis S (2014) Quantifying the role of fire in the Earth system - Part 2: Impact on the net carbon balance of global terrestrial ecosystems for the 20th century. Biogeosciences 11:1345-1360

18. Yue C, Ciais P, Cadule P, Thonicke K, van Leeuwen TT (2015) Modelling the role of fires in the terrestrial carbon balance by incorporating SPITFIRE into the global vegetation model ORCHIDEE - Part 2: Carbon emissions and the role of fires in the global carbon balance. Geosci Model Dev 8:1321-1338 
19. Poulter B, Cadule P, Cheiney A, et al (2015) Sensitivity of global terrestrial carbon cycle dynamics to variability in satellite-observed burned area. Global Biogeochem Cycles 29:207222

20. Yang J, Tian H, Tao B, Ren W, Lu C, Pan S, Wang Y, Liu Y (2015) Century-scale patterns and trends of global pyrogenic carbon emissions and fire influences on terrestrial carbon balance. Global Biogeochem Cycles 29:1549-1566

21. Higgins SI, Scheiter S (2012) Atmospheric CO2 forces abrupt vegetation shifts locally, but not globally. Nature 488:209-212

22. Baudena M, Dekker SC, van Bodegom PM, et al (2015) Forests, savannas, and grasslands: bridging the knowledge gap between ecology and Dynamic Global Vegetation Models. Biogeosciences 12:1833-1848

23. Lasslop G, Brovkin V, Reick CH, Bathiany S, Kloster S (2016) Multiple stable states of tree cover in a global land surface model due to a fire-vegetation feedback. Geophys Res Lett 43:6324-6331

24. Yue C, Ciais P, Zhu D, Wang T, Peng SS, Piao SL (2016) How have past fire disturbances contributed to the current carbon balance of boreal ecosystems? Biogeosciences 13:675690

25. Braakhekke MC, Rebel KT, Dekker SC, Smith B, Beusen AHW, Wassen MJ (2017) Nitrogen leaching from natural ecosystems under global change: a modelling study. Earth Syst Dynam 8:1121-1139

26. Bauters M, Drake TW, Verbeeck $\mathrm{H}$, et al (2018) High fire-derived nitrogen deposition on central African forests. Proc Natl Acad Sci USA 115:549-554 - This study provides observations of nitrogen redistribution, a high nitrogen deposition flux in a central Afrian forest and attribute the deposition to fire emissions.

27. Wang R, Balkanski Y, Boucher O, Ciais P, Peñuelas J, Tao S (2015) Significant contribution of combustion-related emissions to the atmospheric phosphorus budget. Nature Geosci 8:4854

28. Pacifico F, Folberth GA, Sitch S, Haywood JM, Rizzo LV, Malavelle FF, Artaxo P (2015) Biomass burning related ozone damage on vegetation over the Amazon forest: a model sensitivity study. Atmospheric Chemistry and Physics 15:2791-2804

29. Yue X, Strada S, Unger N, Wang A (2017) Future inhibition of ecosystem productivity by increasing wildfire pollution over boreal North America. Atmospheric Chemistry and Physics 17:13699-13719

30. Andela N, Morton DC, Giglio L, et al (2017) A human-driven decline in global burned area. Science 356:1356-1362 •• They report a human driven decline in global burned area observed by satellites, related to increased intensity of land management.

31. Erb K-H, Luyssaert S, Meyfroidt P, et al (2017) Land management: data availability and process understanding for global change studies. Glob Chang Biol 23:512-533

32. Li F, Lawrence DM, Bond-Lamberty B (2018) Human impacts on 20th century fire dynamics and implications for global carbon and water trajectories. Glob Planet Change 162:18-27 
33. Arora VK, Melton JR (2018) Reduction in global area burned and wildfire emissions since 1930s enhances carbon uptake by land. Nat Commun 9:1326

34. Lasslop G, Kloster S (2017) Human impact on wildfires varies between regions and with vegetation productivity. Environmental Research Letters 12:115011

35. Landry J-S, Partanen A-I, Damon Matthews H (2017) Carbon cycle and climate effects of forcing from fire-emitted aerosols. Environmental Research Letters 12:025002

36. Jiang Y, Lu Z, Liu X, Qian Y, Zhang K, Wang Y, Yang X-Q (2016) Impacts of global open-fire aerosols on direct radiative, cloud and surface-albedo effects simulated with CAM5. Atmospheric Chemistry and Physics 16:14805-14824

37. Jacobson MZ (2014) Effects of biomass burning on climate, accounting for heat and moisture fluxes, black and brown carbon, and cloud absorption effects. J Geophys Res Atmos 119:8980-9002

38. Grandey BS, Lee H-H, Wang C (2016) Radiative effects of interannually varying vs. interannually invariant aerosol emissions from fires. Atmospheric Chemistry and Physics 16:14495-14513

39. Voulgarakis A, Marlier ME, Faluvegi G, Shindell DT, Tsigaridis K, Mangeon S (2015) Interannual variability of tropospheric trace gases and aerosols: The role of biomass burning emissions. J Geophys Res Atmos 120:7157-7173

40. Thornhill GD, Ryder CL, Highwood EJ, Shaffrey LC, Johnson BT (2018) The effect of South American biomass burning aerosol emissions on the regional climate. Atmospheric Chemistry and Physics 18:5321-5342

41. Hodnebrog $\varnothing$, Myhre G, Forster PM, Sillmann J, Samset BH (2016) Local biomass burning is a dominant cause of the observed precipitation reduction in southern Africa. Nat Commun 7:11236 - This study provides a model-based attribution of precipitation reduction to fire shows that a reduction of local biomass burning aerosol emissions may mitigate reduced rainfall.

42. Tosca MG, Diner DJ, Garay MJ, Kalashnikova OV (2014) Observational evidence of fire-driven reduction of cloud fraction in tropical Africa. J Geophys Res Atmos 119:8418-8432

43. Hamilton DS, Hantson S, Scott CE, Kaplan JO, Pringle KJ, Nieradzik LP, Rap A, Folberth GA, Spracklen DV, Carslaw KS (2018) Reassessment of pre-industrial fire emissions strongly affects anthropogenic aerosol forcing. Nat Commun 9:3182

44. van der Werf GR, Randerson JT, Giglio L, et al (2017) Global fire emissions estimates during 1997-2016. Earth Syst Sci Data 9:697-720

45. Reddington CL, Spracklen DV, Artaxo P, Ridley DA, Rizzo LV, Arana A (2016) Analysis of particulate emissions from tropical biomass burning using a

global aerosol model and long-term surface observations. Atmospheric Chemistry and Physics 16:11083-11106

46. Veira A, Kloster S, Schutgens NAJ, Kaiser JW (2015) Fire emission heights in the climate system - Part 2: Impact on transport, black carbon concentrations and radiation.

Atmospheric Chemistry and Physics 15:7173-7193 
47. Veira A, Lasslop G, Kloster S (2016) Wildfires in a warmer climate: Emission fluxes, emission heights, and black carbon concentrations in 2090-2099. J Geophys Res Atmos 121:31953223

48. Boucher O, Randall D, Artaxo P, et al (2014) Clouds and Aerosols. In: Intergovernmental Panel on Climate Change (ed) Climate Change 2013 - The Physical Science Basis. Cambridge University Press, Cambridge, pp 571-658

49. Li F, Lawrence DM, Bond-Lamberty B (2017) Impact of fire on global land surface air temperature and energy budget for the 20th century due to changes within ecosystems. Environ Res Lett 12:44014

50. Rogers BM, Soja AJ, Goulden ML, Randerson JT (2015) Influence of tree species on continental differences in boreal fires and climate feedbacks. Nature Geosci 8:228-234 •• They explain the variation between continents in fire regimes and fire climate impacts in the boreal regions by plant trait variation.

51. Yang J, Pan S, Dangal S, Zhang B, Wang S, Tian H (2017) Continental-scale quantification of post-fire vegetation greenness recovery in temperate and boreal North America. Remote Sensing of Environment 199:277-290 • This study shows that the variation in post-fire recovery can be explained by differences in vegetation composition and fire severity.

52. Chen D, Loboda TV, He T, Zhang Y, Liang S (2018) Strong cooling induced by stand-replacing fires through albedo in Siberian larch forests. Sci Rep 8:4821 - For stand replacing fires in Siberia the impact of fire on albedo induces a similar cooling as in North America.

53. Chen D, Loboda TV (2018) Surface forcing of non-stand-replacing fires in Siberian larch forests. Environmental Research Letters 13:045008

54. Liu Z, Ballantyne AP, Cooper LA (2018) Increases in land surface temperature in response to fire in siberian boreal forests and their attribution to biophysical processes. Geophys Res Lett 45:6485-6494

55. Liu Z, Ballantyne AP, Cooper LA (2019) Biophysical feedback of global forest fires on surface temperature. Nat Commun 10:214

56. Turetsky MR, Kane ES, Harden JW, Ottmar RD, Manies KL, Hoy E, Kasischke ES (2011) Recent acceleration of biomass burning and carbon losses in Alaskan forests and peatlands. Nature Geosci 4:27-31

57. Gibson CM, Turetsky MR, Cottenie K, Kane ES, Houle G, Kasischke ES (2016) Variation in plant community composition and vegetation carbon pools a decade following a severe fire season in interior Alaska. J Veg Sci 27:1187-1197

58. Trugman AT, Fenton NJ, Bergeron Y, Xu X, Welp LR, Medvigy D (2016) Climate, soil organic layer, and nitrogen jointly drive forest development after fire in the North American boreal zone. J Adv Model Earth Syst 8:1180-1209

59. Alexander HD, Mack MC, Goetz S, Beck PSA, Belshe EF (2012) Implications of increased deciduous cover on stand structure and aboveground carbon pools of Alaskan boreal forests. Ecosphere 3:45

60. Veraverbeke S, Rogers BM, Goulden ML, Jandt RR, Miller CE, Wiggins EB, Randerson JT 
(2017) Lightning as a major driver of recent large fire years in North American boreal forests. Nat Clim Chang 7:529-534

61. Yu Z, Loisel J, Brosseau DP, Beilman DW, Hunt SJ (2010) Global peatland dynamics since the Last Glacial Maximum. Geophys Res Lett. doi: 10.1029/2010GL043584

62. Page SE, Hooijer A (2016) In the line of fire: the peatlands of Southeast Asia. Philos Trans R Soc Lond, B, Biol Sci. doi: 10.1098/rstb.2015.0176

63. Turetsky MR, Benscoter B, Page S, Rein G, van der Werf GR, Watts A (2015) Global vulnerability of peatlands to fire and carbon loss. Nature Geosci 8:11-14

64. Santín C, Doerr SH, Kane ES, Masiello CA, Ohlson M, de la Rosa JM, Preston CM, Dittmar T (2016) Towards a global assessment of pyrogenic carbon from vegetation fires. Glob Chang Biol 22:76-91 • They review the pyrogenic carbon cycle and compiled stocks and fluxes in the global pyrogenic carbon cycle.

65. Dargie GC, Lewis SL, Lawson IT, Mitchard ETA, Page SE, Bocko YE, Ifo SA (2017) Age, extent and carbon storage of the central Congo Basin peatland complex. Nature 542:86-90

66. Tarnocai C, Canadell JG, Schuur EAG, Kuhry P, Mazhitova G, Zimov S (2009) Soil organic carbon pools in the northern circumpolar permafrost region. Global Biogeochem Cycles. doi: 10.1029/2008GB003327

67. Wiggins EB, Czimczik Cl, Santos GM, Chen Y, Xu X, Holden SR, Randerson JT, Harvey CF, Kai FM, Yu LE (2018) Smoke radiocarbon measurements from Indonesian fires provide evidence for burning of millennia-aged peat. Proc Natl Acad Sci USA 115:12419-12424 • The quantification of the age of peat burning indicates how low it will take until carbon pools could recover from fire.

68. Wilkinson SL, Moore PA, Flannigan MD, Wotton BM, Waddington JM (2018) Did enhanced afforestation cause high severity peat burn in the Fort McMurray Horse River wildfire? Environmental Research Letters 13:014018

69. Konecny K, Ballhorn U, Navratil P, Jubanski J, Page SE, Tansey K, Hooijer A, Vernimmen R, Siegert $F$ (2016) Variable carbon losses from recurrent fires in drained tropical peatlands. Glob Chang Biol 22:1469-1480

70. Han J, Tangdamrongsub N, Hwang C, Abidin HZ (2017) Intensified water storage loss by biomass burning in Kalimantan: Detection by GRACE. J Geophys Res Solid Earth. doi: 10.1002/2017JB014129

71. Gibson CM, Chasmer LE, Thompson DK, Quinton WL, Flannigan MD, Olefeldt D (2018) Wildfire as a major driver of recent permafrost thaw in boreal peatlands. Nat Commun 9:3041

72. Köster E, Köster K, Berninger F, Prokushkin A, Aaltonen H, Zhou X, Pumpanen J (2018) Changes in fluxes of carbon dioxide and methane caused by fire in Siberian boreal forest with continuous permafrost. J Environ Manage 228:405-415

73. Song X, Wang G, Hu Z, Ran F, Chen X (2018) Boreal forest soil CO2 and CH4 fluxes following fire and their responses to experimental warming and drying. Science of The Total Environment 644:862-872 
74. Li F, Levis S, Ward DS (2013) Quantifying the role of fire in the Earth system - Part 1: Improved global fire modeling in the Community Earth System Model (CESM1).

Biogeosciences 10:2293-2314

75. Eliseev AV, Mokhov II, Chernokulsky AV (2014) An ensemble approach to simulate $\mathrm{CO}_{2}$ emissions from natural fires. Biogeosciences 11:3205-3223

76. Wagner S, Jaffé R, Stubbins A (2018) Dissolved black carbon in aquatic ecosystems. Limnol Oceanogr 3:168-185

77. Bird MI, Wynn JG, Saiz G, Wurster CM, McBeath A (2015) The pyrogenic carbon cycle. Annu Rev Earth Planet Sci 43:273-298

78. Reisser M, Purves RS, Schmidt MWI, Abiven S (2016) Pyrogenic Carbon in Soils: A LiteratureBased Inventory and a Global Estimation of Its Content in Soil Organic Carbon and Stocks. Front Earth Sci. doi: 10.3389/feart.2016.00080

79. Bao H, Niggemann J, Luo L, Dittmar T, Kao S-J (2017) Aerosols as a source of dissolved black carbon to the ocean. Nat Commun 8:510

80. Coppola Al, Ziolkowski LA, Masiello CA, Druffel ERM (2014) Aged black carbon in marine sediments and sinking particles. Geophys Res Lett 41:2427-2433

81. Coppola Al, Wiedemeier DB, Galy V, et al (2018) Global-scale evidence for the refractory nature of riverine black carbon. Nature Geosci 11:584-588

82. Marques JSJ, Dittmar T, Niggemann J, Almeida MG, Gomez-Saez GV, Rezende CE (2017) Dissolved Black Carbon in the Headwaters-to-Ocean Continuum of Paraíba Do Sul River, Brazil. Front Earth Sci. doi: 10.3389/feart.2017.00011

83. Coppola Al, Druffel ERM (2016) Cycling of black carbon in the ocean. Geophys Res Lett 43:4477-4482

84. Wang X, Xu C, Druffel EM, Xue Y, Qi Y (2016) Two black carbon pools transported by the Changjiang and Huanghe Rivers in China. Global Biogeochem Cycles 30:1778-1790

85. Roebuck JA, Seidel M, Dittmar T, Jaffé R (2018) Land use controls on the spatial variability of dissolved black carbon in a subtropical watershed. Environ Sci Technol 52:8104-8114

86. Fuss S, Lamb WF, Callaghan MW, et al (2018) Negative emissions-Part 2: Costs, potentials and side effects. Environmental Research Letters 13:063002

87. Landry J-S, Matthews HD (2017) The global pyrogenic carbon cycle and its impact on the level of atmospheric $\mathrm{CO} 2$ over past and future centuries. Glob Chang Biol 23:3205-3218

88. Harrison SP, Bartlein PJ, Brovkin V, Houweling S, Kloster S, Prentice IC (2018) The biomass burning contribution to climate-carbon-cycle feedback. Earth Syst Dynam 9:663-677

89. Giglio L, Boschetti L, Roy DP, Humber ML, Justice CO (2018) The Collection 6 MODIS burned area mapping algorithm and product. Remote Sens Environ 217:72-85

90. Chuvieco E, Lizundia-Loiola J, Pettinari ML, et al (2018) Generation and analysis of a new global burned area product based on MODIS $250 \mathrm{~m}$ reflectance bands and thermal anomalies. Earth Syst Sci Data 10:2015-2031

91. Giglio L, Csiszar I, Justice CO (2006) Global distribution and seasonality of active fires as 
observed with the Terra and Aqua Moderate Resolution Imaging Spectroradiometer (MODIS) sensors. J Geophys Res. doi: 10.1029/2005JG000142

92. Kaiser JW, Heil A, Andreae MO, et al (2012) Biomass burning emissions estimated with a global fire assimilation system based on observed fire radiative power. Biogeosciences 9:527-554

93. Giglio L, Randerson JT, van der Werf GR (2013) Analysis of daily, monthly, and annual burned area using the fourth-generation global fire emissions database (GFED4). J Geophys Res Biogeosci 118:317-328

94. Randerson JT, Chen Y, van der Werf GR, Rogers BM, Morton DC (2012) Global burned area and biomass burning emissions from small fires. J Geophys Res 117:G04012

95. Long T, Zhang Z, He G, Jiao W, Tang C, Wu B, Zhang X, Wang G, Yin R (2018) 30m resolution Global Annual Burned Area Mapping based on Landsat images and Google Earth Engine. arXiv e-prints arXiv:1805.02579

96. Goodwin NR, Collett $L$ (2014) Development of an automated method for mapping fire history captured in Landsat TM and ETM+ time series across Queensland, Australia. Remote Sensing of Environment 148:206-221

97. White JC, Wulder MA, Hermosilla T, Coops NC, Hobart GW (2017) A nationwide annual characterization of 25 years of forest disturbance and recovery for Canada using Landsat time series. Remote Sensing of Environment 194:303-321

98. Hawbaker TJ, Vanderhoof MK, Beal Y-J, et al (2017) Mapping burned areas using dense timeseries of Landsat data. Remote Sensing of Environment 198:504-522

99. Verhegghen A, Eva H, Ceccherini G, Achard F, Gond V, Gourlet-Fleury S, Cerutti P (2016) The potential of sentinel satellites for burnt area mapping and monitoring in the congo basin forests. Remote Sens (Basel) 8:986

100. Roteta E, Bastarrika A, Padilla M, Storm T, Chuvieco E (2019) Development of a Sentinel-2 burned area algorithm: Generation of a small fire database for sub-Saharan Africa. Remote Sensing of Environment 222:1-17

101. Laurent P, Mouillot F, Yue C, Ciais P, Moreno MV, Nogueira JMP (2018) FRY, a global database of fire patch functional traits derived from space-borne burned area products. Sci Data 5:180132

102. Andela N, Morton DC, Giglio L, Paugam R, Chen Y, Hantson S, van der Werf GR, Randerson JT (2018) The Global Fire Atlas of individual fire size, duration, speed, and direction. Earth Syst Sci Data Discuss 1-28

103. Lohberger S, Stängel M, Atwood EC, Siegert F (2018) Spatial evaluation of Indonesia's 2015 fire-affected area and estimated carbon emissions using Sentinel-1. Glob Chang Biol 24:644654

104. Atwood EC, Englhart S, Lorenz E, Halle W, Wiedemann W, Siegert F (2016) Detection and Characterization of Low Temperature Peat Fires during the 2015 Fire Catastrophe in Indonesia Using a New High-Sensitivity Fire Monitoring Satellite Sensor (FireBird). PLoS ONE 11:e0159410 
105. Alonzo M, Morton DC, Cook BD, Andersen H-E, Babcock C, Pattison R (2017) Patterns of canopy and surface layer consumption in a boreal forest fire from repeat airborne lidar. Environmental Research Letters 12:065004

106. Chasmer LE, Hopkinson CD, Petrone RM, Sitar M (2017) Using multitemporal and multispectral airborne lidar to assess depth of peat loss and correspondence with a new active normalized burn ratio for wildfires. Geophys Res Lett 44:11,851-11,859

107. Simpson J, Wooster M, Smith T, Trivedi M, Vernimmen R, Dedi R, Shakti M, Dinata Y (2016) Tropical peatland burn depth and combustion heterogeneity assessed using UAV photogrammetry and airborne lidar. Remote Sens (Basel) 8:1000

108. Prat-Guitart N, Rein G, Hadden RM, Belcher CM, Yearsley JM (2016) Effects of spatial heterogeneity in moisture content on the horizontal spread of peat fires. Sci Total Environ 572:1422-1430

109. Huang X, Rein G (2017) Downward spread of smouldering peat fire: the role of moisture, density and oxygen supply. Int J Wildland Fire 26:907

110. Lukenbach MC, Hokanson KJ, Moore PA, Devito KJ, Kettridge N, Thompson DK, Wotton BM, Petrone RM, Waddington JM (2015) Hydrological controls on deep burning in a northern forested peatland. Hydrol Process 29:4114-4124

111. Glukhova TV, Sirin AA (2018) Losses of Soil Carbon upon a Fire on a Drained Forested Raised Bog. Eurasian Soil Sc 51:542-549

112. Stavros EN, Coen J, Peterson B, Singh H, Kennedy K, Ramirez C, Schimel D (2018) Use of imaging spectroscopy and LIDAR to characterize fuels for fire behavior prediction. Remote Sensing Applications: Society and Environment 11:41-50

113. Veraverbeke S, Dennison P, Gitas I, Hulley G, Kalashnikova O, Katagis T, Kuai L, Meng R, Roberts D, Stavros N (2018) Hyperspectral remote sensing of fire: State-of-the-art and future perspectives. Remote Sensing of Environment 216:105-121

114. van Leeuwen TT, van der Werf GR, Hoffmann AA, et al (2014) Biomass burning fuel consumption rates: a field measurement database. Biogeosciences 11:7305-7329

115. Rogers BM, Veraverbeke S, Azzari G, Czimczik Cl, Holden SR, Mouteva GO, Sedano F, Treseder KK, Randerson JT (2014) Quantifying fire-wide carbon emissions in interior Alaska using field measurements and Landsat imagery. J Geophys Res Biogeosci 119:1608-1629

116. Walker XJ, Rogers BM, Baltzer JL, Cumming SG, Day NJ, Goetz SJ, Johnstone JF, Schuur EAG, Turetsky MR, Mack MC (2018) Cross-scale controls on carbon emissions from boreal forest megafires. Glob Chang Biol. doi: 10.1111/gcb.14287

117. Wiggins EB, Veraverbeke S, Henderson JM, et al (2016) The influence of daily meteorology on boreal fire emissions and regional trace gas variability. J Geophys Res Biogeosci 121:2793-2810

118. Marlon JR, Kelly R, Daniau A-L, et al (2016) Reconstructions of biomass burning from sediment-charcoal records to improve data-model comparisons. Biogeosciences 13:32253244

119. van Marle MJE, Kloster S, Magi BI, et al (2017) Historic global biomass burning emissions for 
CMIP6 (BB4CMIP) based on merging satellite observations with proxies and fire models (1750-2015). Geosci Model Dev 10:3329-3357 